\title{
How good are equity valuation models in predicting stock prices?
}

\author{
Christoph Hukelmann \\ BDO AG, Hamburg, Germany \\ Christoph.hukelmann@bdo.de \\ Cesario Mateus \\ Department of Accounting and Finance \\ University of Greenwich Business School, London, United Kingdom \\ c.mateus@greenwich.ac.uk \\ Irina Mateus \\ Department of Accounting, Finance and Governance \\ University of Westminster Business School, London, United Kingdom \\ i.bezhentseva@westminster.ac.uk
}

\begin{abstract}
This paper aims to test the accuracy of three well-known equity valuation models for the period 1990 to 2006. This was done to a sample of German listed firms which diverge from the US market in accounting standards, market maturity and corporate governance culture (bank-based in contrast to the market-based US regime) as well as different market movements and trends which influence main input factors and estimations (e.g. market risk premium, inflation rate and GDP growth rate). To the best of our knowledge this is the first paper to address this issue for a sample of listed firms from the largest bank-based European economy.

Using different accuracy measures such as absolute prediction error (average, median and central tendency) as well as multiple regression analysis the results show that dividend discount and abnormal earnings models tend to provide better accuracy than the free cash flow approach. Additionally, we find evidence of the importance in German accounting standards in the less accurate performance of the abnormal earnings model compared to previous studies due to the conservative accounting and the influence of hidden reserves. Finally, we did not find any significant valuation differences regarding the alternative values used for growth and discount rates.
\end{abstract}

Keywords: Accounting standards, Equity Valuation models, prediction error, Value of Firm

JEL Classification: G3, G32 


\section{Introduction}

Accurate equity valuation is very important for investors, analysts, managers and other stakeholders in the companies. Kenneth French in his Presidential Address to the American Finance Association in 2008, provided evidence that for the period between 1980 to 2006 investors spent on average 0.67 percent of the aggregate value of the market each year searching for superior returns. This amounts to a total spending of 101.8 billion dollars in 2006 just for the US market shows the importance of company valuation and stock price prediction as an active research area in finance. Practitioners require valuation models to make better investment decisions, reduce risk of bad choices and allocate resources efficiently. Despite this intensive research and the theoretical simplicity of most of the valuation models, literature does neither give a definitive answer regarding the superiority of a specific model nor the best practice for the implementation of these models. Although there are a number of studies that identify a specific model to be more accurate than others under certain conditions, there is no consensus and the search for a generally superior valuation model remains a puzzle. Empirical results in particular differ when different assumptions for the inputs are made and the way data comparison is drawn. The studies testing the accuracy of company valuation models has been mainly done for the USA market and in particular discussing the discounted cash flows, discounted dividends and abnormal earnings models as well multiples such as the price-earnings ratio (Farooq et al [2010], Cassia et al [2009], Jorgensen, Lee and Yoo [2005], Francis et al [2000], Penman and Sougiannis [1998]). Additionally studies has focused in specific industries and company similarities such as high growth rates, recent IPOs or leveraged transactions (Berkman, Bradbury and Ferguson [2000], Kaplan and Ruback [1995]).

The aim of this paper is twofold: First, to test the accuracy of three well-known equity valuation models for the German stock market which diverge from the US market in accounting standards, market maturity and corporate governance culture (bank-based in contrast to the marketbased US regime) as well as different market movements and trends which influence main input factors and estimations (e.g. market risk premium, inflation rate and GDP growth rate). To the best of our knowledge this is the first paper to address this issue for a sample of listed firms from the largest bank-based European economy. Secondly, to contribute to the debate regarding the precision of valuation models and the fundamental idea behind the intrinsic value calculation.

The results suggest that the dividend discount and abnormal earnings models tend to provide better accuracy than the free cash flow approach. Additionally, we find evidence of the importance of German accounting standards in the less accurate performance of the abnormal earnings model compared to previous studies due to the conservative accounting and the influence of hidden reserves. Finally, we did not find any significant valuation differences regarding the alternative values used for growth and discount rates.

The remainder of the paper is organized as follows. In section 2 the main issues in the inputs estimation and previous empirical results are discussed. In section 3 the sample selection, variables and valuation models are presented. The empirical analysis results are in section 4 and section 5 concludes.

\section{Valuation Models, Issues and previous Empirical Results 2.1 Valuation Models}

Previous studies tend to compare dividend discount, discounted cash flows and abnormal earnings models as intrinsic valuation approaches (Cassia et al, 2009; Courteau et al, 2001; Francis et al 2000; Pennan et al 1998, among others). Multiple based models are rather discussed separately or seen as an addition to the previous three models (Liu, Nissim and Thomas, 2002 and Kaplan et al, 1995). The main reason for the focus on models which value firms directly or determine the intrinsic value rather than compare to other company or companies is related to the practical issue of 
identifying accurate comparable companies. Additionally, there is a lack of evidence which from so many possible comparable is the most correct one to use (Kaplan et al, 1995). Finally, the three previously named intrinsic valuation models are all based on the same theoretical school which accepts that value is determined by discounted expected future streams of payoffs (Francis et al, 2000). Among practitioners the free cash flow and dividend discount models complemented with multiples valuations are the most common procedure making the abnormal earnings model less widespread (Faroq et al, 2010 and Demirakos et al). Although there is consensus that models based on discounted cash flows, discounted dividends as well as abnormal earnings should in theory provide the same valuation if applied for an infinite time horizon, empirical results shows that valuation results differ (Jorgensen et al, 2005; Pennman, 2001; Francis et al, 2000; Courteau et al, 2001, among others). These practical differences might occur if input factors are not consistent or a finite model horizon is applied (Pennam, 2001 and Francis et al, 2000). Contrary to this Lundholm and O'Keefe (2001) reject the assumption that different models are allowed to yield different valuations even if applied in a finite rather than infinite time horizon. Differing results are driven by incorrect application of the model, forecast issues and incorrect discount rates. Thus the problematic approach of a finite forecasting period but an infinite payoff expectation is recognized but accepted for practical reasons. Consequently, for practical reasons a comparison of the different models is sensible and important as it contributes to the understanding of company valuation. Other sources for valuation differences are violations of clean surplus accounting or inconsistent assumptions for forecasts, discount or growth rates are nor constant (Francis et al, 2000). Finally, another criticism of company valuations based on accounting figures was given by Shiller (1981) who argues that market based values are generally too volatile to be justified by accounting figures.

\subsection{Issues and assumptions}

The accuracy models measures differ in several aspects. Courteau et al (2001) and Francis et al (2000) use a simple approach that measures the prediction exactitude by comparing the mean intrinsic firm value with the mean actual market prices. ${ }^{1}$ Francis et al (2000) additionally test the central tendency and Courteau et al (2001) divide the valuation in its components and analyse the skewness and standard deviation of the model outcomes. In contrast, Penman et al (1998) measure model accuracy by forming random portfolios to eliminate market inefficiencies and average out the unpredictable component using ex-post data. A different approach is followed by Courteau et al (2006) who assumes market price inefficiencies and valuation model superiority. In this setting a model it is seen superior if generates higher abnormal return. This means the market under/overvalues stocks and investors can achieve abnormal returns by estimating the true intrinsic value.

Another important distinction among previous studies is the source of data used. The main differences are whether the input factors are based on realised data (ex-post) or analysts' forecasts (ex-ante). Berkman et al (2000), Francis et al (2000) and Kaplan et al (1995) use analysts' forecasts as the core input data for their firm valuation models and compare it to observed market prices on the forecasted day. In contrast, Penman et al (1998) use historical data to replicate time series of data and compare their valuation to the actual market value of the firm on the valuation date. Forecast data might not be available for all firms and all years or be biased (Francis et al, 2000). Easterwood et al (1999) and Easton and Sommers (2007) shown that on average an upward bias of analysts' forecast is observed. In addition, Francis et al (2000) and Gode and Mohanran (2003) detected

\footnotetext{
${ }^{1}$ This requires that the market price is seen as efficient and therefore as an unbiased estimation of the true value of a company (Henschke, 2009 and Vorfeld, 2009). Consequently, valuation differences between the market price and model estimation can be interpreted as a bad performance of the model itself. Empirical studies show that capital markets are rather efficient (Malkiel, 2003; Blake, 2000; Fama, 1970 and 1998).
} 
significant noise in forecasted data. However, Jorgensen et al (2005) highlighted that this noise decreases and valuations improve as longer forecast horizons are implemented.

Depending on the model applied different approaches are followed for what discount rate to use. Francis et al (2000), Berkman et al (2000) and Kaplan et al (1995) use the cost of equity for the dividend discount and abnormal earnings models but the weighted average cost of capital for the free cash flow model. In contrast, Cassia (2009) and Koller et al (2005) apply the weighted average cost of capital as discount rate for the abnormal earnings and free cash flow models and Penman et al (1998) and Corteau et al (2001) use the cost of equity in all three models. Nevertheless the CAPM is the most common model used to calculate the cost of equity; the three input factors (market beta, risk free rate and market risk premium) differ in practice and among different empirical studies. Although the market risk premium is assumed to be between 5 and 6 percent in most of the academic papers and text books some studies differ significantly from these values such as Berkman et al (2000), Kaplan et al (1995) and Penman et al (1998) that use 7, 7.42 and 8 percent, respectively. In terms of proxy for the risk free rate some studies use 10 years treasury bonds (Jorgensen et al, 2005, Liu et al, 2002, among others) while others use shorter or longer maturities. Berkman et al (2000) use a different approach by matching the maturity of their risk free rate with the expected cash flows plus the 10 years government bond yield for the terminal value. In terms of the market beta calculation Francis et al (2000) use industry and firm specific betas, Berkman et al (2000) industry and market betas and Kaplan et al (1995) firm, industry and market specific betas. However as referred by Bruner et al (1998) the main sources of estimation differences are the observation period and the market index used. By last the terminal growth rate is an important input factor with significant influence on the terminal value. Kaplan et al (1995) find evidence that differing growth rates are important factor that might influence the valuation accuracy. Penman et al (1998) and Francis et al (2000) shown that model accuracy increases if positive growth rates are used compared to a zero growth assumption. The long term inflation rate is seen the most sensible terminal growth rate by several authors (Francis et al, Kaplan et al, 1995, Penman et al, Berkman et $a l, 200$ among others).

\subsection{Empirical Results}

Overall, the empirical results are not consistent and it is observed that the model application and accuracy measurement has significant influence on the results obtained. Jorgensen et al (2005), Francis et al (2000) and Pennman et al (1998) observe that the abnormal earnings model is superior to the free cash flow and dividend discount models. The abnormal earnings model in particular is superior compared to other models when accounting distortion is less severe than forecasting errors (Francis et al, 2000) which require a clean surplus accounting where all assets and liabilities changes pass through the income statement (Ohlson, 1995). ${ }^{2}$ Studies show that the clean surplus assumption is regularly violated and significant deviations between different accounting standards can be observed (Harris et al, 1994, King et al, 1998, Isidro, O'Hanlon and Young, 2006) and as discussed in King et al (1998) the German accounting standards have less violations of clean surplus than other accounting standards. ${ }^{3}$ Altogether, more accurate the terminal value can be predicted the better the free cash flow and dividend discount models will perform while the abnormal earnings model benefit from accounting accuracy and from few violation of clean surplus accounting. Kaplan et al (1995) find evidence that firms' market beta is an important factor and firm specific betas

\footnotetext{
${ }^{2}$ Clean surplus can be formally stated as $y_{t-1}=y_{t}+d_{t}-x_{t}$; with $\mathrm{y}$ equal to the net book value, $\mathrm{x}$ equal to earnings and d equal to net dividend (Feltham and Ohlson, 1995)

${ }^{3}$ Until 2004 German companies reported following the German HGB standards (additional reporting following international standards was voluntarily). Since 2005 quoted firms have to report following the IFRS standards (King et al, 2003 and Behringer, 2003).
} 
provide less accurate results than industry based betas. Penman et al (1998) and Francis et al (2000) stated that discount rate is a minor input since no significant deviations are found for different discount rates.

The empirical findings from previous studies not only show different results regarding the relevance of each model but also that the accuracy is very diverse depending on the inputs factors variation, sample collection and number of forecasted periods. As reported in Faroq et al (2005), Francis et al (2000), Penman et al (1998) and Kaplan et al (1995) the estimation errors tend to be more than $50 \%$.

\section{Sample selection, variables and valuation models}

\subsection{Sample selection and variables}

The primary accounting data is from Worldscope database. The sample includes all companies of the DAX 30 index for the period 1990 to $2010^{4}$, representing about 80 percent of the market capitalization of German stock market and listed at the Frankfurt Stock Exchange (Deutsche Boerse, 2010). Financial institutions and insurance companies are excluded from the sample due to their differing valuation requirements. For each company the financial statement and end of year stock value for at least four years after valuation were needed. A minimum of 23 and a maximum of 25 companies fulfilled the requirements each year. For four companies the essential information was not available and in six other cases the required data was available but not for all years. Due to missing information the sample size was reduced to 29 unique companies, 333 valuations per model and set of assumptions (4,995 unique valuations in total). The loss of 19 percent of firm year observations follows previous studies with rates between 15 and 25 percent (Liu et al, 2002, Courteau et al, 2001, Berkman et al, 2000 and Francis et al, 2000).

The estimations for the different attributes are based on economic key figures for the German market. An interesting figure is that the corporate marginal tax rate constantly decreases over the 20 years of the sample (from 60 percent in 1990 to 29 percent in 2010). ${ }^{5}$ The corporate tax rate is settled equal for each company as the aggregate country average in each year. The firm's capital structure was assumed unchanged for the terminal value calculation. Therefore, a constant weighted average cost of capital and cost of equity capital are assumed for each firm ${ }^{6}$. Return on equity was calculated applying the Capital Asset Pricing Model using both company and industry current specific betas provided by Thomson ONE, risk free rate was proxied using the one and ten year German government bond yields for each year and the return on firm's debt as the ratio between the interest expenses and the long plus short term debt. ${ }^{7}$ The market risk premium was calculated as the average for the DAX 30 from the period 1974 to 2010 and stated as 4.85 percent.

Table 1 summarizes the different assumptions implemented for each model used in the valuation estimation.

\footnotetext{
${ }^{4}$ Since the valuation models are tested with a three year forecast horizon and one year observation for the terminal value 2006 is the last year for which valid valuations are made using accounting and market data until 2010.

5 The corporate tax rate in Germany is partly relying on trade tax and a solidarity surcharge. Therefore, company's taxation might vary depending on their location. In 2010 the corporate tax rate consisted of a 15\% corporate income tax, $0.825 \%(5.5 \%$ of $15 \%)$ solidarity surcharge and an average local trade tax of $13.585 \%$.

${ }^{6}$ Francis et al (2000) suggest the use of a target capital structure while Berkman et al (2000) proposes duration matched discount rates. The methodology implemented in this paper assumes that the actual discount rate and capital structure in each year are known and constant after the planning period.

${ }^{7}$ Due to some distortions in company's financial reports a minimum (10 year government bond yield) and maximum (10 year government bond yield plus 2.868 percent) value for the cost of debt was used. It is assumed that the expected return on debt is stable and consequently the debt is fairly priced at its book value. The use of market values does not apply for this sample since as bank based financial system debt is, on generally, not publicly traded.
} 
Table 1: Valuation Input factors

\begin{tabular}{|c|c|c|c|}
\hline Factor & Symbol & Definition & Value \\
\hline \multirow[t]{3}{*}{ Growth $^{8}$} & G1 & Consumer price index & $1.91 \%$ \\
\hline & G2 & Real growth, inflation adjusted GDP & $1.68 \%$ \\
\hline & G3 & Equal to zero & $0 \%$ \\
\hline Corporate Tax Rate & MTR & $\begin{array}{l}\text { Equal to each company and set at the average } \\
\text { corporate tax rate of each year }\end{array}$ & \\
\hline Market risk premium & & $\begin{array}{l}\text { Average DAX } 30 \text { market risk premium from } \\
1974 \text { to } 2010\end{array}$ & $4.85 \%$ \\
\hline \multirow[t]{3}{*}{ Discount Rate } & D1 & $\begin{array}{l}10 \text { year government bond yield and specific } \\
\text { company beta }\end{array}$ & Unique per firm \\
\hline & D2 & $\begin{array}{l}10 \text { year government bond yield and industry } \\
\text { beta }\end{array}$ & Unique per industry \\
\hline & D3 & $\begin{array}{l}1 \text { year government bond yield and specific } \\
\text { company beta }\end{array}$ & Unique per firm \\
\hline
\end{tabular}

In this paper the dividend discount, free cash flow and abnormal earnings models are tested for a three-year forecast horizon. The three-year together with a five-year period are the most common approaches in practice (Homburg et al, 2011). We use realised returns instead of analysts' forecasts to avoid forecast's bias and to achieve a more complete data set with exact input factors such as dividends and cash flows and the accuracy measured following the approach by Penman et al (1998) where all individual firms in each year are assigned to a portfolio and pooled over time. To increase the explanatory power of the analysis in the different models the accuracy is measured by different indicators. Firstly, we calculate average/mean and median bias and absolute prediction error as the percentage deviation of the estimations and the observed market value on the valuation date. Secondly, the central tendency is defined as the percentage of valuations that are within a range of 15 percent of the observed market value and the standard deviation of the annual average price estimates to the average annual observed market prices. Finally, it is tested if sample adjustments influence the accuracy ranking, in particular, the elimination of negative value valuations and outliers.

\subsection{Valuation Models}

\subsubsection{Free cash flow model}

In this model the value of a company is determined as the present value of future cash flows plus excess cash and marketable securities minus debt and preferred shares. Since the valuation is completely dependent on future expectations, the model is vulnerable to different inputs, in particular, as observed by Francis et al (2000) on average 82 percent of the firm value is determined by the terminal value. The free cash flow model is specified as follows (Francis et al, 2000):

$$
\begin{gathered}
V_{F C F}=\sum_{t=1}^{T}(1+W A C C)^{-t} F C F_{t}+(1+W A C C)^{-T} T V_{F C F}+E C M S-D-P S \\
F C F=(\text { Sales }- \text { OpeExp }- \text { DepExp }) \times\left(1-\tau_{C}\right)+\text { DepExp }-\Delta W C-\text { CapExp } \\
T V=\frac{F C F_{T+1}}{W A C C-g}
\end{gathered}
$$

where, V is the market value, WACC the weighted average cost of capital, FCF the free cash flow, TV the terminal value, ECMS the excessive cash and marketable securities, D is debt, OpeExp the

\footnotetext{
${ }^{8}$ Homburg et al (2011), Corteau et al (2001), Francis et al (2000), Penman et al (1998) and Kaplan (1995).
} 
operating expenses, DepExp depreciation expenses, WC working capital CapExp the capital expenditures, PS refer to preference shares, $\tau_{\mathrm{C}}$ represents corporate taxes and $\mathrm{g}$ the expected $\mathrm{FCF}$ growth.

\subsubsection{Abnormal earnings model}

The abnormal earnings model also known as residual income or economic profit model, values a company based on the book value of invested capital and the present value of expected abnormal earnings (Feltham and Ohlson, 1995) defined as the difference between the actual return (net operating profit after taxes) and the expected return on invested capital. Since parts of the valuation are based on book values, this model is less sensitive to future forecasts than the free cash flow or dividend discount models. As reported in Francis et al (2000) the book value accounts for 72 percent of the firm's valuation on average giving to the abnormal earnings model some advantage in relation to other models. However, a possible drawback of the abnormal earnings model is that accounting based profits could be misleading if no clean surplus accounting is given (Koller et al, 2005). The abnormal earnings model is formally specified as follows:

$$
\begin{gathered}
V_{A E}=I C_{B V}+\sum_{t=1}^{T}(1+W A C C)^{-t} A E_{t}+(1+W A C C)^{-T} T V_{A E}+E C M S-D-P S \\
A E=\left(R O I C_{t}-W A C C_{t}\right) \times I C_{B V} \\
T V_{A E}=\frac{A E_{T+1}}{W A C C-g}
\end{gathered}
$$

where, IC is the invested capital (book value), AE is the abnormal return and ROIC is calculated as Net Operating Profit Less Adjusted Taxes divided by Invested Capital

\subsubsection{Dividend discount model}

In the dividend discount model the value of the company is determined by the present value of its future net dividend payments. Although dividends tend to be relatively stable over short and medium time horizons, the long term dividend is difficult to predict and since the model is very sensitive to the terminal value, which according to Francis et al (2000) accounts for 65 percent of the valuation, the model is exposed to dividends that are very hard to forecast. Moreover, the model is difficult to implement in practice because of the future dividends should be net dividends meaning that they should include not only cash dividends but all payments that are made to the shareholders e.g. share repurchases. However, payments that are made indirectly to shareholders such as share buybacks cannot be observed directly from the company's financial statements and consequently difficult to implement in practice. ${ }^{9}$ The dividend discount model can be expressed in the form:

$$
\begin{gathered}
V_{D D M}=\sum_{t=1}^{T}\left(1+r_{E}\right)^{-t} d_{t}+\left(1+r_{E}\right)^{-T} T V_{D D M} \\
T V_{D D M}=\frac{d_{T+1}}{r_{E}-g}
\end{gathered}
$$

\footnotetext{
${ }^{9}$ Penman et al (1998) use for dividend calculation the change in the outstanding shares number (adjusted for stock splits and reverse splits). By multiplying the number of repurchased shares with the stock price they calculate the additional cash distribution to shareholders besides the regular dividends. Unfortunately, due to the lack of data this approach is not implemented in this study.
} 
where, $r_{E}$ is the return on equity and $d$ the dividend paid.

\section{Results}

Table 2 reports the mean/median price estimates, standard deviation and central tendency of the three models for the five different specifications presented previously in Table 1 . The central tendency measures the percentage of value estimates within $15 \%$ of the observed market price. Negative value estimates are included but set at zero which affects 1.417 of the 4.995 observations ${ }^{10}$. When measured by the mean percentage difference the dividend discount and abnormal earnings models tend to underestimate the average stock market price (average negative predicted signed error) and the FCF model overestimates the stock price, on average. When the median is used the results show an under prediction. This is the result of the large number of negative valuations in particular for the case of the free cash flow model.

Table 2: Valuation Accuracy: Signed prediction error (values in percentage)

The market prices are observed market prices on the forecast date. The mean and median prediction errors signs are calculated as $(V-P) / P$, with $\mathrm{V}$ equal to the estimated value from the valuation models and $\mathrm{P}$ is equal to the observed market price. The absolute prediction error is equal to $|(V-P) / P|$. The central tendency measures the percentage of value estimates within $15 \%$ of the observed market price. Standard deviation is calculated between the mean annual share price estimates and the mean annual observed market prices.

\begin{tabular}{lccccc}
\hline Free Cash Flow & Model 1 & Model 2 & Model 3 & Model 4 & Model 5 \\
\hline Average & 69.99 & 56.80 & 93.25 & 66.15 & 47.41 \\
Average (\% Difference) & $139.3 \%$ & $93.6 \%$ & $210.6 \%$ & $126.1 \%$ & $62.9 \%$ \\
Median & 3.32 & 2.45 & 4.74 & 3.67 & 2.46 \\
Median (\% Difference) & $-87.2 \%$ & $-88.4 \%$ & $-80.5 \%$ & $-87.3 \%$ & $-89.7 \%$ \\
Standard Deviation & 75.80 & 58.65 & 100.69 & 71.20 & 49.65 \\
\hline Abnormal Earnings & Model & Model 2 & Model 3 & Model 4 & Model 5 \\
\hline Average & 20.55 & 17.21 & 28.97 & 20.08 & 18.11 \\
Average (\% Difference) & $-36.4 \%$ & $-46.8 \%$ & -13.75 & $-37.7 \%$ & $-43.0 \%$ \\
Median & 5.25 & 4.02 & 6.82 & 5.86 & 7.66 \\
Median (\% Difference) & $-74.0 \%$ & $-79.8 \%$ & $-68.2 \%$ & $-71.9 \%$ & $-66.8 \%$ \\
Standard Deviation & 19.82 & 17.66 & 30.13 & 19.11 & 15.91 \\
\hline Dividend Discount & Model & Model 2 & Model 3 & Model 4 & Model 5 \\
\hline Average & 12.86 & 10.71 & 17.57 & 12.49 & 10.43 \\
Average (\% Difference) & $-55.6 \%$ & $-63.2 \%$ & $-41.8 \%$ & $-56.9 \%$ & $-64.0 \%$ \\
Median & 8.45 & 7.13 & 10.90 & 8.22 & 7.04 \\
Median (\% Difference) & $-64.2 \%$ & $-69.0 \%$ & $-53.9 \%$ & $-64.9 \%$ & $-70.4 \%$ \\
Standard Deviation & 11.63 & 11.89 & 11.42 & 11.69 & 12.12 \\
\hline
\end{tabular}

Table 3 provides the results for the absolute prediction error. For all the five specifications the abnormal earnings model shows the lowest bias and the absolute prediction error illustrates that the free cash flow model has the largest average price deviation for all the five different specifications. The average prediction accuracy of the dividend discount model outperforms the other two models in four out of five specifications resulting also in a better median value estimates with an average prediction error of 66.56 percent. However, this consistency of the dividend discount model does not generally provide superior estimations if these are measured by central

\footnotetext{
1035,616 and 766 observations for the dividend discount, abnormal earnings and free cash flow models, respectively. The replace of negative valuations by zero assumes that a company that continues to generate negative cash flows or negative abnormal earnings will not survive (Gode et al, 2003 and Francis et al, 2000). Later these negative valuations are excluded from the sample and their influence on the valuation accuracy is tested.
} 
tendency, especially if the discount rate is high or growth expectation low (the central tendency of the dividend discount model decreases). ${ }^{11}$

Table 3: Valuation Accuracy: Absolute Prediction Error (values in percentage)

\begin{tabular}{lccccc}
\hline Free Cash Flow & Model 1 & Model 2 & Model 3 & Model 4 & Model 5 \\
\hline Average & 198.9 & 158.2 & 262.60 & 187.90 & 140.90 \\
Median & 100.00 & 100.00 & 100.00 & 100.00 & 100.00 \\
Central Tendency & 4.52 & 6.93 & 6.02 & 4.52 & 5.72 \\
\hline Abnormal Earnings & & & & & \\
\hline Average & 75.10 & 71.4 & 88.80 & 73.4 & 64.4 \\
Median & 95.60 & 94.70 & 100.00 & 93.90 & 79.0 \\
Central Tendency & 7.53 & 7.23 & 4.82 & 7.53 & 9.34 \\
\hline Dividend Discount & & & & & \\
\hline Average & 61.30 & 63.70 & 48.80 & $62.00 \%$ & 65.80 \\
Median & 66.20 & 70.60 & 57.30 & $67.20 \%$ & 71.50 \\
Central Tendency & 8.13 & 3.31 & 7.23 & $7.53 \%$ & 3.31 \\
\hline
\end{tabular}

Industry betas are on average significantly higher than firm specific betas (1.23 and 0.96 respectively) ${ }^{12}$ and, as a consequence, discount rates are higher and therefore intrinsic prices are lower. This is because of the industry average betas considered not only large listed firms (DAX 30) but also other listed firms in the German market with higher systematic risk. Overall, the abnormal earnings model shows the highest average central tendency values followed by the dividend discount and free cash flow models.

Table 4 reports the same information as on Table 3 but with exclusion of negative estimates and extreme values. ${ }^{13}$ The free cash flow model approach loses accuracy when measured by the average prediction error caused by a very small number of outliers in a reduced number of companies.

\footnotetext{
${ }^{11}$ This is the case of specification/model 5 with a growth estimation of zero but also specification/model 2 where industry betas are used.

${ }^{12}$ The difference between firma and industry betas is very consistent ( 25 of 31 industry betas were higher than the firm's betas). Bruner et al (1998) and Kaplan et al (1998) observed similar deviations.

${ }^{13}$ With this procedure $0.025 \%$ of each tail of the distribution was eliminated with a total of 25 estimates referring to 3 companies being 21 of these outliers from free cash flow model, 4 from abnormal earnings and none from dividend discounted model estimates.
} 
Table 4: Valuation Accuracy: Absolute Prediction Error (values in percentage)

\begin{tabular}{|c|c|c|c|c|c|}
\hline Free Cash Flow & Model 1 & Model 2 & Model 3 & Model 4 & Model 5 \\
\hline \multicolumn{6}{|l|}{ Negative values excluded } \\
\hline Average & 277.20 & 215.80 & 378.10 & 259.10 & 174.70 \\
\hline Median & 82.70 & 69.90 & 101.40 & 81.10 & 64.20 \\
\hline Central Tendency & 8.33 & 12.78 & 11.11 & 8.33 & 10.61 \\
\hline \multicolumn{6}{|l|}{ Outliers excluded } \\
\hline Average & 55.5 & 45.60 & 73.10 & 52.50 & 46.00 \\
\hline Median & 100.00 & 100.00 & 100.00 & 100.00 & 100.00 \\
\hline Central Tendency & 4.57 & 7.01 & 6.12 & 4.57 & 5.79 \\
\hline \multicolumn{6}{|c|}{ Negative and Outliers excluded } \\
\hline Average & 78.70 & 59.60 & 118.20 & 72.00 & 41.30 \\
\hline Median & 81.40 & 69.00 & 98.20 & 80.70 & 61.40 \\
\hline Central Tendency & 8.52 & 13.07 & 11.43 & 8.52 & 10.86 \\
\hline \multicolumn{6}{|l|}{ Abnormal Earnings } \\
\hline \multicolumn{6}{|l|}{ Negative values excluded } \\
\hline Average & 72.20 & 69.00 & 88.80 & 69.90 & 60.10 \\
\hline Median & 59.40 & 62.70 & 67.70 & 59.90 & 54.70 \\
\hline Central Tendency & 12.20 & 12.00 & 7.77 & 11.96 & 13.54 \\
\hline \multicolumn{6}{|l|}{ Outliers excluded } \\
\hline Average & 69.10 & 71.40 & 73.70 & 67.70 & 64.40 \\
\hline Median & 95.60 & 94.70 & 100.00 & 93.90 & 79.00 \\
\hline Central Tendency & 7.55 & 7.23 & 4.85 & 7.55 & 9.34 \\
\hline \multicolumn{6}{|c|}{ Negative and Outliers excluded } \\
\hline Average & 65.60 & 69.00 & 70.00 & 63.70 & 60.10 \\
\hline Median & 59.40 & 62.70 & 67.20 & 59.60 & 54.70 \\
\hline Central Tendency & 12.25 & 12.00 & 7.84 & 12.02 & 13.54 \\
\hline \multicolumn{6}{|l|}{ Dividend Discount } \\
\hline \multicolumn{6}{|l|}{ Negative values excluded } \\
\hline Average & 61.00 & 63.40 & 48.50 & 61.70 & 65.50 \\
\hline Median & 65.90 & 70.40 & 57.10 & 66.70 & 71.30 \\
\hline Central Tendency & 8.28 & 3.37 & 7.36 & 7.67 & 3.37 \\
\hline \multicolumn{6}{|l|}{ Outliers excluded } \\
\hline Average & 61.30 & 63.70 & 48.80 & 62.00 & 65.80 \\
\hline Median & 66.20 & 70.60 & 57.30 & 67.20 & 71.50 \\
\hline Central Tendency & 8.13 & 3.31 & 7.23 & 7.53 & 3.31 \\
\hline \multicolumn{6}{|c|}{ Negative and Outliers excluded } \\
\hline Average & 61.00 & 63.40 & 48.50 & 61.70 & 65.50 \\
\hline Median & 65.90 & 70.40 & 57.10 & 66.70 & 71.30 \\
\hline Central Tendency & 8.28 & 3.37 & 7.36 & 7.67 & 3.37 \\
\hline
\end{tabular}

The central tendency of the free cash flow and abnormal earnings models improves for all five specifications (from 5.5 to 10.2 percent and 7.3 to 11.5 percent, respectively) as these were the ones more affected by the zero valuations shown in Table 2 . When outliers are excluded the free cash flow model results are the most accurate following by the dividend discount and abnormal earnings models. When both negative valuations and outliers are excluded there is a general further improvement of the median valuation accuracy and central tendency. The results clearly illustrate that different specifications have a considerable influence in the models ranking. The abnormal earnings model tends to beat the other approaches for all growth measures as far firm's specific beta and 10 year government bond yields are used with central tendency values between 12.02 and 13.54. However, as shown in Figure 1 the average bias continuously changed over the sample period. While in early 90's all three models underestimated the stock value, over the following years the underestimation decreased or moved to an overestimation for the free cash flow and abnormal earnings models. 
Figure 1: Average bias per model and year

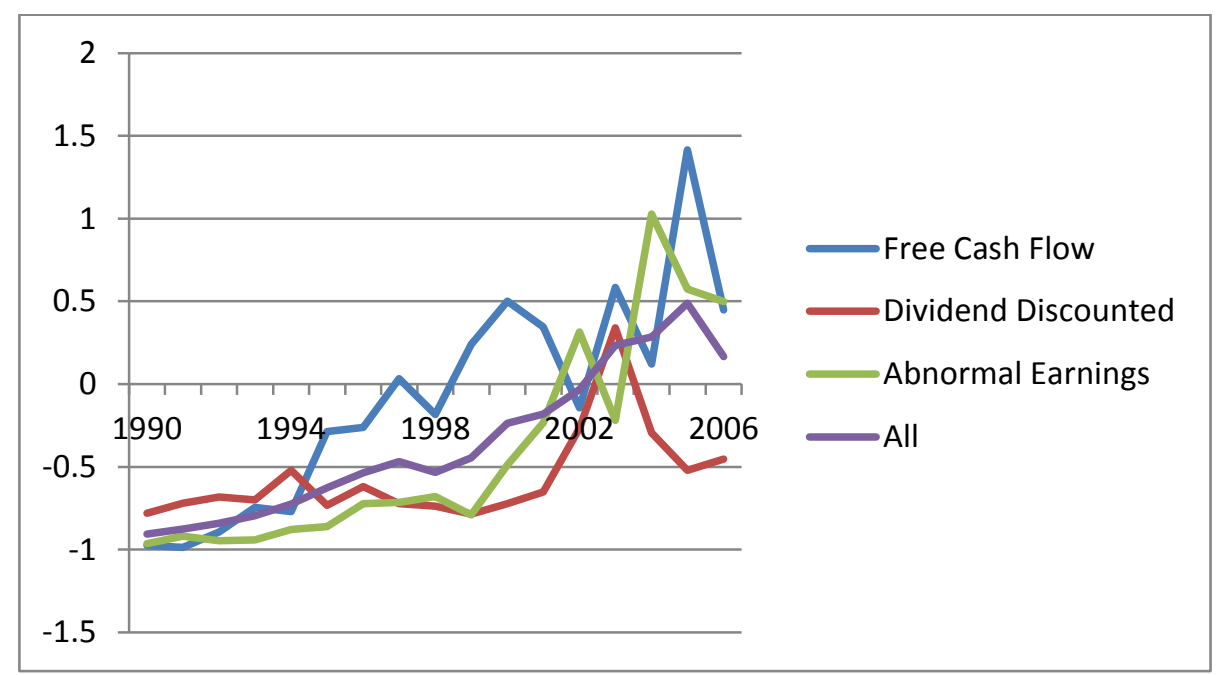

One plausible reason for this pattern change was the different accounting standards profile during the sample period. Indeed as discussed by Wuestmann (2003) 92.8 percent of DAX 30 companies used HGB accounting standards in 1995 declined along the years to 13.33 percent in 2001. King et al (1998) and Harris et al (1984) highlighted that German accounting standards ${ }^{14}$ are less related to market values than market-based oriented IFRS and Anglo-American accounting standards. King et al (1998) report a systematic downward bias for the value estimates based on German accounting standards caused in particular by a very conservative accounting and the influence of hidden reserves (Stille Reserven). ${ }^{15}$ Figure 2 reports the percentage of companies in DAX 30 that between 1995 and 2001 used HGB, IFRS and US-GAPP, respectively. The change in accounting standards is visible and can be seen as a potential reason for the increasing company value estimates in relation to the observed market value and, in particular, to the systematic underestimation during the early years of this study.

\footnotetext{
${ }^{14}$ Handelsgesetzbuch (HGB), law that governs the primary commercial code for companies in Germany. Regulation related to the preparation of financial statements is included in the law. This law is similar to GAAP which is followed in the United States.

${ }^{15}$ Hidden reserves (Stille Reserven) are equity assets due to the undervaluation (overvaluation) of assets (liabilities) and therefore do not arise in the balance sheet of a company. Companies use these valuation possibilities of the HGB standards to transfer tax liabilities to the future and to increase profit continuity. With IAS hidden reserves are seen as a violation of company's fair reports (Heno, 2006).
} 
Figure 2: Accounting Standards of DAX 30 companies

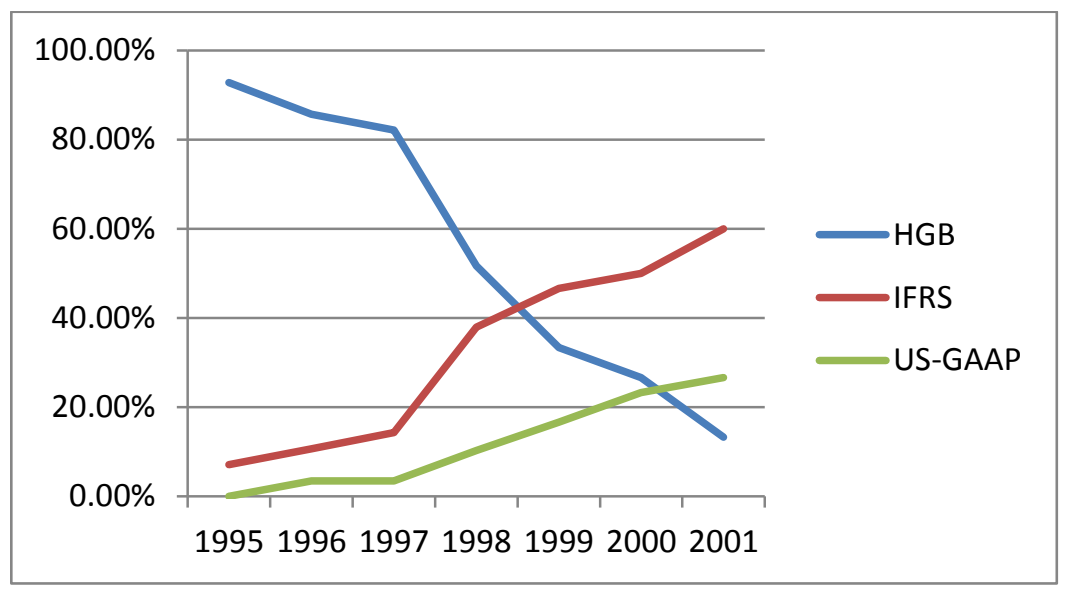

Additionally, these accounting differences might be responsible for the less accurate performance of the abnormal earnings model compared to previous studies as this model significantly relies on the book value of invested capital. Since the book value is systematically undervalued under German accounting rules the abnormal earnings model estimates are also downward biased. However, a conflict between the findings of King et al (1998), who examined that HGB accounting standards has less clean surplus violations than other accounting standards, and Francis et al (2000), who reports that the abnormal earnings model perform well when clean surplus, can be identified. Additionally, some other patterns can be identified: first, the increase in volatility of the valuation bias during the years might also be related with the changes in the accounting standards; second, the observed trend of a constantly increasing value estimates to market price ratio shows that the aftermath of the financial crisis from 2007-2009 are priced in these estimations; third, the decrease in the corporate tax rate from 1990 to 2010 has a decline effect on corporate tax shield on the one side but also the cash flows and after tax profits increases on the other side. While the cash flows and after tax profits increase have a positive influence on value estimations the decreasing tax shield has the opposite effect due to the increase in the required rate of return. ${ }^{16}$ Finally, the decreasing of German government bonds yield caused steady decline in the discount rates and therefore an increase in the stock price estimates.

In Table 5 is reported the correlation matrix for the price estimations across the three different models and five different specifications. One can highlight the very high correlation among the different specifications for each model analysed showing that differences in the input factors do not alter the price predictions significantly.

\footnotetext{
${ }^{16}$ Higher after tax profits directly influence the abnormal earnings model estimations due to higher abnormal returns and indirectly in the dividend discounted model estimations due to higher profits in form of dividends to the shareholders.
} 
Table 5: Pearson's Correlation Matrix for Equity valuation models

\begin{tabular}{|c|c|c|c|c|c|c|c|c|c|c|c|c|c|c|}
\hline FCF 1 & DDM 1 & $\mathrm{AE} 1$ & FCF 2 & DDM 2 & $\mathrm{AE} 2$ & FCF 3 & DDM 3 & $\mathrm{AE} 3$ & FCF 4 & DDM 4 & $\mathrm{AE} 4$ & FCF 5 & DDM 5 & $\mathrm{AE} 5$ \\
\hline FCF 1 & 1.000 & & & & & & & & & & & & & \\
\hline DDM 1 & 0.037 & 1.000 & & & & & & & & & & & & \\
\hline $\mathrm{AE} 1$ & 0.565 & 0.082 & 1.000 & & & & & & & & & & & \\
\hline FCF 2 & 0.999 & 0.035 & 0.575 & 1.000 & & & & & & & & & & \\
\hline DDM 2 & 0.044 & 0.975 & 0.121 & 0.044 & 1.000 & & & & & & & & & \\
\hline AE 2 & 0.547 & 0.082 & 0.996 & 0.559 & 0.128 & 1.000 & & & & & & & & \\
\hline FCF 3 & 0.993 & 0.039 & 0.624 & 0.993 & 0.047 & 0.605 & 1.000 & & & & & & & \\
\hline DDM 3 & 0.046 & 0.981 & 0.143 & 0.044 & 0.976 & 0.141 & 0.054 & 1.000 & & & & & & \\
\hline AE 3 & 0.519 & 0.088 & 0.993 & 0.528 & 0.129 & 0.984 & 0.581 & 0.165 & 1.000 & & & & & \\
\hline FCF 4 & 0.997 & 0.037 & 0.577 & 0.998 & 0.045 & 0.560 & 0.988 & 0.045 & 0.531 & 1.000 & & & & \\
\hline DDM 4 & 0.041 & 0.999 & 0.088 & 0.039 & 0.980 & 0.088 & 0.043 & 0.982 & 0.094 & 0.041 & 1.000 & & & \\
\hline $\mathrm{AE} 4$ & 0.527 & 0.106 & 0.994 & 0.538 & 0.160 & 0.991 & 0.586 & 0.176 & 0.989 & 0.540 & 0.113 & 1.000 & & \\
\hline FCF 5 & 1.000 & 0.037 & 0.567 & 1.000 & 0.044 & 0.549 & 0.993 & 0.046 & 0.521 & 0.998 & 0.041 & 0.529 & 1.000 & \\
\hline DDM 5 & 0.038 & 1.000 & 0.082 & 0.036 & 0.976 & 0.082 & 0.040 & 0.981 & 0.089 & 0.038 & 0.999 & 0.107 & 0.038 & 1.000 \\
\hline AE 5 & 0.560 & 0.084 & 1.000 & 0.570 & 0.125 & 0.996 & 0.619 & 0.147 & 0.993 & 0.572 & 0.090 & 0.995 & 0.562 & 0.085 \\
\hline
\end{tabular}

Across the models lower correlation is observed between the free cash flow and the abnormal earnings models with the dividend discount model (average correlations of 0.041 and 0.09 , respectively) showing that the latest is capturing different aspects of the valuation.

As a complementary analysis a multivariate regression analysis is implemented to test the explanation power of each model on firms' market prices. The following equation is estimated using a pooled sample across firms and time from 1990 to 2006.

Observable Price $_{i, t}=\alpha+\beta_{E P}$ Estimated Price $_{i, t}+\beta_{M R}$ Market Return $_{t}+\beta_{\text {Year }}$ Year $+\beta_{\text {Firm }}$ Firm $_{t}+\varepsilon_{i t}$

Where "observable price" is the firm's market price in each year divided by the average price for the sample period, EP is the estimated price variable calculated in two ways: estimated price divided by its average over the sample period (EP1) and standardized price defined as the difference between predicted and observable price scaled by the standard deviation of the first difference among predicted and observable price for each firm (EP2), "Market Index" is the DAX 30 index in each year divided by its average for the sample period, Year is a dummy variable equal to one if year before 2002 and zero otherwise ${ }^{17}$, firm is a firm dummy variable and $\varepsilon$ is the error term.

Table 6 reports the results when each model is tested individually with the two approaches used in terms of the proxy for the price prediction variable.

\footnotetext{
${ }^{17}$ After 2001 most of the firms in the sample used IFRS or US-GAAP (see Figure 2)
} 
Table 6: Multiple Regression Analysis

The sample consists of 333 firm-year estimations for the period 1990-2006. The following regression is estimated: Observable Price $_{i, t}=\alpha+\beta_{E P}$ Estimated Price $_{i, t}+\beta_{M R}$ Market Return $_{t}+\beta_{\text {Year }}$ Year $+\beta_{\text {Firm }}$ Firm $_{t}+\varepsilon_{i t}$, where "observable price" is the firm's market price in each year divided by the average price for the sample period, EP is the estimated price variable calculated in two ways: estimated price divided by its average over the sample period (EP1) and standardized price defined as the difference between predicted and observable price scaled by the standard deviation of the first difference among predicted and observable price for each firm (EP2), "Market Index" is the DAX 30 index in each year divided by its average for the sample period, Year is a dummy variable equal to one if year before 2002 and zero otherwise and $\varepsilon$ is the error term.

\begin{tabular}{|c|c|c|c|c|c|c|}
\hline & Model 1 & Model 2 & Model 3 & Model 4 & Model 5 & Model 6 \\
\hline Constant & $\begin{array}{c}0.3125^{*} \\
(2.622)\end{array}$ & $\begin{array}{c}0.3469^{*} \\
(2.973)\end{array}$ & $\begin{array}{c}0.2163 * \\
(2.662)\end{array}$ & $\begin{array}{l}0.3670^{*} \\
(5.6183)\end{array}$ & $\begin{array}{c}0.3177 * \\
(2.990)\end{array}$ & $\begin{array}{l}0.4353^{*} \\
(4.389)\end{array}$ \\
\hline Market Index & $\begin{array}{l}0.608^{*} \\
(7.010)\end{array}$ & $\begin{array}{l}0.6372 * \\
(7.551)\end{array}$ & $\begin{array}{l}0.6008^{*} \\
(12.153)\end{array}$ & $\begin{array}{c}0.5370^{*} \\
(5.618)\end{array}$ & $\begin{array}{c}0.5155^{* *} \\
(6.316)\end{array}$ & $\begin{array}{c}0.5831 * \\
(7.981)\end{array}$ \\
\hline EP1_FCF & $\begin{array}{c}0.0261 \\
(0.5960)\end{array}$ & ----- & ----- & ----- & ----- & ----- \\
\hline EP2_FCF & ----- & $\begin{array}{c}-0.0591 * * \\
(-2.063)\end{array}$ & ----- & ----- & ----- & ----- \\
\hline EP1_DDM & ----- & ----- & $\begin{array}{c}0.1311^{*} \\
(3.654)\end{array}$ & ----- & ----- & ----- \\
\hline EP2_DDM & ----- & ----- & ----- & $\begin{array}{c}-0.0949^{*} \\
(-7.501)\end{array}$ & ----- & ----- \\
\hline EP1_AE & ----- & ----- & ----- & ----- & $\begin{array}{c}0.1231^{*} \\
(2.414)\end{array}$ & ----- \\
\hline EP2_AE & ----- & ----- & ----- & ----- & ----- & $\begin{array}{c}-0.01131 * \\
(-4.092)\end{array}$ \\
\hline Year_Dummy & $\begin{array}{c}0.0061 \\
(0.0897)\end{array}$ & $\begin{array}{l}-0.0326 \\
(-0.482)\end{array}$ & $\begin{array}{l}0.0593 \\
(1.127)\end{array}$ & $\begin{array}{c}-0.0981 * * \\
(-2.104)\end{array}$ & $\begin{array}{l}0.0811 \\
(1.100)\end{array}$ & $\begin{array}{c}-0.1358 * * \\
(-1.929)\end{array}$ \\
\hline Fixed Effects & YES & YES & YES & YES & YES & YES \\
\hline $\begin{array}{l}\mathrm{Nr} \\
\text { Observations }\end{array}$ & 173 & 171 & 318 & 317 & 197 & 195 \\
\hline Adj. R-squared & 0.241 & 0.269 & 0.384 & 0.461 & 0.270 & 0.430 \\
\hline
\end{tabular}

The results show a strong significance of the estimated price proxies used for both the dividend and abnormal earnings model. In the case of the free cash flow model the results are not significant in its first specification confirming the discussion from Table 3 where the outliers were not excluded. Additionally, there is a strong statistically significant evidence of the market index variable on the firm's observable price proxy. On average, an increase (decrease) of one percent of the index from its average value has a positive (negative) effect on the dependent variable between 0.51 and 0.63 . Additionally, one regress the natural logarithm of the predicted prices in the natural logarithm of the observable prices (using the market index and the year dummy as control variables). Results are shown in Table 7 where the proxy for the free cash flow estimated prices is 
not significant when combined with the other two models. The market index variable is positive and statistically significant (coefficients between 0.22 and 0.65 ) and the dividend discount model shows evidence of better prediction followed by the abnormal earnings model. In fact for both (all models and single model regressions) the coefficients of the dividend discount model is higher and statistically significant for one percent level that shows a better prediction than other models. Additionally, the market index variable has more impact on the observable prices in the free cash flow model regressions confirming the weakness of this model for the reasons discussed previously.

Table 7: Multiple Regression Analysis

The sample consists of 333 firm-year estimations for the period 1990-2006. The following regression is estimated as: Observable Price $_{i, t}=\alpha+\beta_{E P}$ Estimated Price $_{i, t}+\beta_{M R}$ Market Return $_{t}+\beta_{\text {Year Year }}+\beta_{\text {Firm }}$ Firm $_{t}+\varepsilon_{i t}$, where "observable price" is the natural logarithm of firm's market price in each year EP is the natural logarithm of the estimated price "Market Index" is the DAX 30 index in each year divided by its average for the sample period, Year is a dummy variable equal to one if year before 2002 and zero otherwise and $\varepsilon$ is the error term.

\begin{tabular}{|c|c|c|c|c|}
\hline & Model & Model 2 & Model 3 & Model 4 \\
\hline Constant & $\begin{array}{l}-2.4796^{*} \\
(-2.635)\end{array}$ & $\begin{array}{l}-1.6689 * \\
(-2.907)\end{array}$ & $\begin{array}{l}0.7343 \\
(0.832)\end{array}$ & $\begin{array}{c}-2.072 \\
(-1.636)\end{array}$ \\
\hline Free Cash Flow & $\begin{array}{c}0.0634 * * \\
(2.288)\end{array}$ & ----- & ----- & $\begin{array}{l}0.0124 \\
(0.383)\end{array}$ \\
\hline Dividend Discount & ----- & $\begin{array}{l}0.2591^{*} \\
(6.834)\end{array}$ & ----- & $\begin{array}{c}0.1843 * \\
(3.282)\end{array}$ \\
\hline Abnormal Earnings & ----- & ---- & $\begin{array}{l}0.1838^{*} \\
(5.004)\end{array}$ & $\begin{array}{c}0.1247 * * \\
(2.108)\end{array}$ \\
\hline Market Index & $\begin{array}{c}0.6549^{*} \\
(5.728)\end{array}$ & $\begin{array}{l}0.5101 * \\
(7.330)\end{array}$ & $\begin{array}{c}0.2267 * * \\
(2.058)\end{array}$ & $\begin{array}{c}0.5197^{*} \\
(3.276)\end{array}$ \\
\hline Dummy_year & $\begin{array}{l}0.0558 \\
(0.665)\end{array}$ & $\begin{array}{l}0.2126^{*} \\
(2.762)\end{array}$ & $\begin{array}{l}0.3062^{*} \\
(3.214)\end{array}$ & $\begin{array}{c}0.2378^{*} \\
(2.259)\end{array}$ \\
\hline $\begin{array}{l}\text { Nr Observations } \\
\text { Adj. R-squared }\end{array}$ & $\begin{array}{c}173 \\
0.225\end{array}$ & $\begin{array}{c}318 \\
0.298\end{array}$ & $\begin{array}{c}197 \\
0.195\end{array}$ & $\begin{array}{c}124 \\
0.314\end{array}$ \\
\hline
\end{tabular}

\section{Conclusions}

The aim of this paper was twofold: Firstly, to test the accuracy of three well-known equity valuation models for the German stock market which diverge from the US market in accounting standards, market maturity and corporate governance culture (bank-based in contrast to the marketbased US regime) as well as different market movements and trends which influence main input factors and estimations (e.g. market risk premium, inflation rate and GDP growth rate). Secondly, to contribute to the debate regarding the precision of valuation models and the fundamental idea behind the intrinsic value calculation.

The results suggest that the dividend discount and abnormal earnings models tend to provide better accuracy than the free cash flow approach. Additionally, we find evidence of the importance of German accounting standards in the less accurate performance of the abnormal earnings model compared to previous studies due to the conservative accounting and the influence of hidden reserves. Moreover, we did not find any significant valuation differences regarding the alternative values used for growth and discount rates. Finally, the overall weak performance of the valuation 
models implemented in this study highlights concerns about such application in bank-based countries where market maturity and corporate governance structure could play an important role in the intrinsic value calculations.

\section{References}

[1] S. (2003) Cash-flow und Unternehmensbeurteilung-Berechnung und Anwendungfelder fuer die Finanzanalyse, $8^{\text {th }}$ edition. Berlin, Schmidt

[2] Berkman, H., Bradbury, M. and Ferguson, J. (2000) 'The Accuracy of Price-Earnings and Discounted Cash Flow Methods of IPO Equity Valuation' Journal of International Financial Management and Accounting. Vol. 11, No 2 71-83

[3] Bruner, R., Eades, K., Harris, R. and Higgins, R. (1998) 'Best Practices in Estimating the Cost of Capital: Survey and Synthesis' Financial Practice and Education. Vol. 8, No 1 13-28

[4] Cassia, L. and Vismara, S. (2009) 'Valuation Accuracy and Infinity Horizon Forecast: Empirical Evidence from Europe' Journal of International Financial Management and Accounting. Vol. 20, No 2 135-165

[5] Courteau, L., Kao, J. and Richardson, G. (2001) 'Equity Valuation Employing the Ideal versus Ad Hoc Terminal Value Expressions' Contemporary Accounting Research. Vol. 18, No 4 625-661

[6] Demirakos, E., Strong, N. and Walker, M. (2004) 'What Valuation Models Do Analysts use?' Accounting Horizons. Vol. 18, No 4 221-240

[7] Easterwood, J. and Nutt, S. (1999) 'Inefficiency in Analysts' Earnings Forecasts: Systematic Misreaction or Systematic Optimism?' The Journal Of Finance. Vol. 54, No 5 1777-97

[8] Easton, P. and Sommers, G. (2007) 'Effect of Analysts' Optimism on Estimates of the Expected Rate of Return Implied by Earnings Forecasts' Journal of Accounting Research. Vol. 45, No 5 983-1015;

[9] Fama, E. (1970) 'Efficient Capital Markets: A Review of Theory and Empirical Work' The Journal of Finance. Vol. 25, No 2383-417

[10] Fama, E. (1998) 'Market efficiency, long-term returns, and behavioural Finance' Journal of Financial Economics. Vol. 49, 283-306

[11] Farooq, S., Ullah, S., Alam, W., Shah, A. (2010) 'The Performance of Equity Valuation Models for High and Low Intangible Companies - A Case of United States' European Journal of Economics, Finance and Administrative Science. Issue 21 141-160

[12] Feltham, G., and Ohlson, J. (1995) 'Valuation and Clean Surplus Accounting for Operating and Financial Activities' Contemporary Accounting Research. Vol. 11, No 2 689-731

[13] Francis, J., Olsson, P. and Oswald, D. (2000) 'Comparing the Accuracy and Explainability of Dividend, Free Cash Flow, and Abnormal Earnings Equity Value Estimates' Journal of Accounting research. Vol. 38, No 1 45-70

[14] French, K. (2008) 'Presidential Address: The Cost of Active Trading' The Journal Of Finance. Vol. 63, No 4 1537-73

[15] Gode, D. and Mohanram, P. (2003) 'Inferring the Cost of Capital Using the Ohlson-Juettner Model' Review of Accounting Studies. Vol. 8, 399-431

[16] Harris, T., Lang, M. and Moeller, H. (1994) 'The Value Relevance of German Accounting Measures: An Empirical Analysis’ Journal of Accounting Research. Vol. 32, No 2 187-209

[17] Heno, R. (2006) Jahresabschluss nach Handelsrecht, Steuerrecht und internationalen Standards (IFRS). 5th Edition. Heidelberg, Physica-Verlag

[18] Henschke, S. (2009) Towards a more accurate equity valuation - An empirical analysis. Wiesbaden, Gabler Research

[19] Homburg, C., Lorens, M. and Sievers, S. (2011) 'Unternehmensbewertung in Deutschland: Verfahren, Finanzplanung und Kapitalkostenermittlung' Controlling and Management. Vol.55, No 2 119-130

[20] Isidro, H., O’Hanlon, J. and Young, S. (2006) 'Dirty Surplus Accounting Flows and Valuation Errors’ Abacus. Vol. 42, No 3 302-44

[21] Jorgensen, B., Lee, Y. and Yoo, Y. (2005) 'An Empirical Assessment of the Valuation Accuracy of the Abnormal Earnings Growth Valuation Model' Working Paper, University of Korea

[22] Kaplan, S. and Ruback, R. (1995) 'The Valuation of Cash Flow Forecasts: An Empirical Analysis' The Journal of Finance. Vol. 50, No 4 1059-1093

[23] Kaplan, S. and Peterson, J. (1998) 'Full-Information Industry Beta' Financial Management. Vol. 27, No 2 8593

[24] King, R. and Langli, J. (1998) 'Accounting Diversity and Firm Valuation' The International Journal of Accounting. Vol. 33, No 5 529-67 
[25] Koller, T., Godehart, M. and Wessels, D (2005) Valuation. Fourth Edition. Hoboken NJ, John Wiley \& Sons

[26] Liu, J., Nissim, D. and Thomas, J. (2002) 'Equity Valuation Using Multiples' Journal of Accounting Research. Vol. 40, No 1 135-172

[27] Lundholm, R. and O'Keefe, T. (2001) 'Reconciling Value Estimates from the Discounted Cash Flow Model and the Residual Income Model' Contemporary Accounting Research. Vol. 18, No 2 311-335

[28] Malkiel, B. G. (2003) 'The Efficient Market Hypothesis and its Critics', Journal of Economic Perspectives, Vol. 17, No 1, winter 2003 59-82

[29] Penman, S. and Sougiannis, T. (1998) 'A comparison of Dividend, Cash Flow, and Earnings approaches to Equity Valuation’ Contemporary Accounting Research. Vol. 15, No 3 343-383

[30] Penman, S. (2001) 'On Comparing Cash Flow and Accrual Accounting Models for use in Equity Valuation' Contemporary Accounting Research. Vol. 18, No 4 681-692

[31] Shiller, R. (1981) 'Do Stock Prices Move Too Much to be Justified by Subsequent Changes in Dividends?', American Economic Review, 71(3) 421-436

[32] Vorfeld, M. (2009) Asset Pricing - Zur Bewertung von unsicheren Cashflows mit zeitvariablen Diskontraten. Wiesbaden, Gabler

[33] Wuestmann (2003) 'Rechnungslegung in Deutschland - Internationalisierungstendenz? Eine empirische Analyse‘ Working paper University of Mannheim, Germany. 